\title{
Amphetamine actions rely on the availability of phosphatidylinositol-4,5-bisphosphate
}

\author{
Florian Buchmayer ${ }^{1}$, Klaus Schicker ${ }^{1}$, Gerald Stübiger ${ }^{1}$, Peter J Hamilton², Petra Geier', Andreas Jurik²,
}

René Weissensteiner ${ }^{3}$, Thomas Steinkellner ${ }^{1}$, Heinrich J Matthies ${ }^{2}$, Therese Montgomery ${ }^{1}$, Marie-Therese Winkler ${ }^{1}$, Jae-Won Yang ${ }^{1}$, Marion Holy ${ }^{1}$, Gerhard F Ecker ${ }^{3}$, Aurelio Galli², Valery Bochkov', Stefan Boehm ${ }^{1}$, Harald H Sitte ${ }^{\text {* }^{*}}$

From 17th Scientific Symposium of the Austrian Pharmacological Society (APHAR). Joint meeting with the Hungarian Society of Experimental and Clinical Pharmacology (MFT)

Innsbruck, Austria. 29-30 September 2011

\section{Background}

Neuronal functions, such as excitability or endo- and exocytosis, require phosphatidylinositol-4,5-bisphosphate $\left(\mathrm{PIP}_{2}\right)$ since ion channels and other proteins involved in these processes are regulated by $\mathrm{PIP}_{2}$. Monoamine transporters control neurotransmission by removing monoamines from the extracellular space. They also display channel properties, but their regulation by $\mathrm{PIP}_{2}$ has not been reported. The psychostimulant amphetamine acts on monoamine transporters to stimulate transportermediated currents and efflux and thereby increases the levels of extracellular monoamines.

\section{Methods and results}

Direct or receptor-mediated activation of phospholipase C (PLC) reduced membrane PIP $_{2}$ and amphetamine-evoked currents through recombinant serotonin transporters; extracellular application of a $\mathrm{PIP}_{2}$-scavenging peptide mimicked this effect. PLC activation also diminished amphetamine-induced reverse transport without altering transmitter uptake. Inhibition of reverse transport by PLC activation was also observed in brain slices and with recombinant dopamine and noradrenaline, but not GABA transporters; rises in intracellular $\mathrm{Ca}^{2+}$ or activation of protein kinase $\mathrm{C}$ were not involved in these effects.

\section{Conclusions}

These data demonstrate for the first time $\mathrm{PIP}_{2}$ dependence of reverse transport and current in monoamine transporters.

\footnotetext{
* Correspondence: harald.sitte@meduniwien.ac.at

${ }^{1}$ Institute of Pharmacology, Center of Physiology and Pharmacology, Medical University of Vienna, 1090 Vienna, Austria

Full list of author information is available at the end of the article
}

\section{Acknowledgements}

Supported by FWF (P22893-B11, P17611, SFB3502, SFB3506), and a grant from NIH DA13975.

\section{Author details}

${ }^{1}$ Institute of Pharmacology, Center of Physiology and Pharmacology, Medical University of Vienna, 1090 Vienna, Austria. ${ }^{2}$ Department of Molecular Physiology and Biophysics, Vanderbilt University, Nashville, TN 37232, USA. ${ }^{3}$ Department of Medicinal Chemistry, University of Vienna, 1090 Vienna, Austria.

Published: 5 September 2011

doi:10.1186/1471-2210-11-S2-A19

Cite this article as: Buchmayer et al:: Amphetamine actions rely on the availability of phosphatidylinositol-4,5-bisphosphate. BMC Pharmacology 2011 11(Suppl 2):A19.

\section{Submit your next manuscript to BioMed Central and take full advantage of: \\ - Convenient online submission \\ - Thorough peer review \\ - No space constraints or color figure charges \\ - Immediate publication on acceptance \\ - Inclusion in PubMed, CAS, Scopus and Google Scholar \\ - Research which is freely available for redistribution \\ Submit your manuscript at www.biomedcentral.com/submit \\ () Biomed Central}

C Biomed Central

(c) 2011 Buchmayer et al; licensee BioMed Central Ltd. This is an open access article distributed under the terms of the Creative Commons Attribution License (http://creativecommons.org/licenses/by/2.0), which permits unrestricted use, distribution, and reproduction in any medium, provided the original work is properly cited. 